\title{
DEFISIT VS SURPLUS FINANSIAL DAN KETERKAITANNYA DENGAN STRUKTUR MODAL
}

\author{
Ida Puspitowati ${ }^{1}$, Kartika Nuringsih ${ }^{2}$ dan Rita Amelinda ${ }^{3}$ \\ ${ }^{1}$ Staf Pengajar Fakultas Ekonomi, Untar Jakarta \\ idap@fe.untar.ac.id \\ ${ }^{2}$ Staf Pengajar Fakultas Ekonomi, Untar Jakarta \\ kartikan@fe.untar.ac.id \\ ${ }^{3}$ Asmawa Lab. Manajemen Keuangan, Untar Jakarta \\ ritaamelinda@gmail.com
}

\begin{abstract}
ABSTRAK
Keputusan pendanaan merupakan kombinasi pendanaan jangka panjang dan jangka pendek dengan mempertimbangkan kemampuan membayar biaya modal kepada investor. Salah satu faktor dipertimbangkan sebelum menambah sumber dana adalah kondisi defisit vs surplus finansial sehingga tujuan riset mengekplorasi kondisi tersebut serta keterkaitanya dengan perubahan struktur utang. Pertama mengidentifikasi kondisi defisit vc surplus finansial berdasarkan pembayaran dividen, investasi jangka panjang, modal kerja bersih dan internal cash flow. Kedua membandingkan jumlah rata-rata penambahan utang jangka panjang antara kondisi surplus dengan deficit. Ketiga menguji efek indikator serta kondisi defisit financial terhadap perubahan utang. Dilakukan observasi 292 sektor manufaktur terdaftar di BEI periode 2008-2013 dengan hasil yaitu: (1) Terdapat perbedaan ratarata perubahan utang jangka panjang antara deficit dengan surplus keuangan, (2) Terdapat pengaruh signifikan 1\% diantara indikator deficit keuangan terhadap perubahan utang. (3) Deficit financial berpengaruh positif signifikan $1 \%$ terhadap perubahan utang. Hasil mengidentifikasi pentingnya deteksi kondisi financial untuk memonitor perubahan struktur utang. Terakhir, disimpulkan bahwa strategi pendanaan belum sepenuhnya menganut pecking order theory, melainkan terjadi kombinasi dengan trade off models.
\end{abstract}

Kata kunci: Utang jangka panjang, defisit vc surplus finansial, pecking order theory, trade off models

\section{PENDAHULUAN}

Dalam teori menajemen keuangan sumber utang memang disarankan sebagai pendanaan bisnis. Menurut pecking order theory dinyatakan pada kondisi normal disarankan mengutamakan sumber dana internal sebelum menggunakan sumber dana utang atau ekuitas (Shyam-Sunder \& Myers, 1999; Chirinko \& Singha, 2000; Frank \& Goyal, 2003). Artinya sumber dana internal diprioritaskan terlebih dahulu sebelum melibatkan kreditor. Ketika sudah memiliki fondasi internal financing cukup kuat, masuknya investor baru lebih memperkokoh struktur modal perusahaan. Kekokohan struktur modal tersebut akan mendukung produktivitas dan profitabilitas sehingga tidak menganggu kemampuan membayar biaya modal. Sebaliknya, ketika mengacu trade off model disarankan menggunakan utang dengan mempertimbangkan trade off antara manfaat dan risiko utang. Kedua pendekatan menarik dikaji sehingga dapat menelaah sejauhmana kondisi pertumbuhan perusahaan. Artinya perusahaan baru tumbuh sangat tidak mungkin menunggu sumber dana internal, tanpa melibatkan pendanaan kreditor. Pertimbangan utama terfokus pada mendapatkan modal dengan biaya relatif rendah sehingga mendukung operasional bisnis secara efisien dan akhirnya mampu membayar kewajiban kepada kreditor.

Sebagai konsekuensi menggunakan utang berarti sangat perlu mendeteksi kondisi defisit vs surplus financial sebelum mengambil utang baru. Perilaku menyisihkan laba ditahan merupakan langkah penting menjaga surplus finansial. Efek keputusan tersebut memiliki korelasi dengan pembayaran dividen, keputusan investasi jangka panjang dan peningkatan modal kerja. Menentukan kondisi defisit finansial bertujuan supaya tepat memutuskan penambahan utang sehingga sumber dana tersebut terserap untuk pendanaan investasi.

Mengidentifikasi kondisi surplus vs defisit financial pada korporasi yang go public berbeda dengan sektor usaha menengah. Pembayaran dividen akan menambah pengeluaran kas, di samping itu masih terdapat pengeluaran kas untuk pendanaan investasi jangka panjang dan investasi jangka pendek. Defisit finansial terjadi ketika sumber dana internal dari laba ditahan tidak mencukupi untuk membiayai ketiga jenis 
pengeluaran tersebut. Ketika pengeluaran kas lebih besar dari sumber dana internal (internal cash flow) terindikasi defisit finansial atau sebaliknya terjadi surplus finansial. Jika pengacu pecking order theory direferensikan bahwa deficit financial dicukupi dengan cara menambah utang atau emisi saham baru. Sebaliknya, ketika surplus dimanfaatkan untuk mengurangi sebagian utang. Dengan mendeteksi kondisi tersebut, digunakan sebagai dasar menentukan kapasitas utang sehingga dapat menekan risiko dari penggunaan utang serta mengembalikan kewajiban secara tepat waktu.

Penelitian mencermati efek kondisi defisit finansial terhadap keputusan utang, diantaranya Khan \& Adom (2015), Atiyet (2012), Akhtar (2005), Cotei \& Farhat (2009), Fosberg (2008), Darminto \& Manurung (2008), Mihov (2005), Vidal \& Ugedo (2005), Frank \& Goyal (2003), Chirinko \& Singha (2000) dan Shyam-Sunder \& Myers (1999). Realitas menunjukan bahwa keputusan pendanaan lebih memilih menambah utang dibandingkan dengan menambah ekuitas. Dengan demikian kapasitas utang yang tinggi berisiko menciptakan financial distress dan konflik keagenan, sehingga diperlukan suatu pendekatan untuk mengevaluasi kondisi defisit vs surplus finansial sebagai pertimbangan dalam memutuskan sumber dana. Mendeteksi kondisi tersebut akan menjaga kinerja manajemen utang atau mencegah konflik kreditor atau pemegang saham. Tujuan paper untuk memberikan gambaran perlunya mempertimbangkan kondisi defisit keuangan ketika merencanakan pendanaan utang sehingga tidak merugikan stakeholder maupun keberlangsungan bisnis. Selain itu untuk mengidentifikasi kembali efek tersebut pada sejumlah perusahaan di BEI. Melalui sektor manufaktur diharapkan teridentifikasi efek deteksi kondisi deficit vs surplus financial dalam penambahan utang. Kajian memfokus tiga rumusan masalah, yaitu: (1) Apakah ada perbedaan antara kedua kondisi finansial dalam menentukan utang jangka panjang?. (2) Seberapa kuat indikator kondisi defisit finansial seperti: dividen, investasi aktiva tetap, modal kerja bersih maupun arus kas internal mempresiksi penambahan utang?.

(3) Seberapa kuat pengaruh defisit finansial terhadap penambahan utang?.

\section{METODE PENELITIAN}

\section{Populasi \& Metode Pengambilan Sampel}

Populasi penelitian berupa laporan keuangan sektor manufaktur di BEI periode 2008-2013. Metode pemilihan sampel menggunakan purposive sampling sesuai Sekaran (2003) dengan kriteria utama menggunakan struktur modal utang. Observasi 4 tahun dengan tujuan menganalisis periode sebelum diberlakukan sistem IFRS dalam akuntansi. Periode selanjutnya akan dilakukan kajian secara terpisah pada riset lanjutan.

\section{Difinisi Operasional Variabel Pertumbuhan Utang}

Perubahan utang sebagai variabel dependen dihitung berdasarkan perubahan total utang dengan tahun berikutnya. Selain itu dikembangkan dengan menggunakan total LTD pada periode berikutnya. Data diambil dari neraca tahun 2008-2013 dengan disimbolkan $\Delta$ LTD dan $\Delta$ Debt. Formulasi sebagai berikut: (Frank and Goyal 2003)
LTD
= Rata-rata LTD dipergunakan pada pengujian $\mathrm{H} 1$
$\Delta$ Debt
$=\left\{\right.$ Debt $_{(t+1)}-$ Debt $\left._{(t)}\right\}$ digunakan pada Pers. 2 dan 3 atau $\mathrm{H} 2$ dan $\mathrm{H} 3$

Keterangan:

Debt $_{(\mathrm{t})} \quad$ : Total utang jangka pendek \& panjang pada periode observasi

Debt $_{(t+1)}$ : Total utang jangka pendek \& panjang tahun berikutnyanya

LTD : Jumlah utang jangka panjang pada periode berikutnya

\section{Defisit Finansial}

Defisit finansial sebagai variable independen diproksi oleh kondisi deficit financial dengan data neraca \& laporan laba rugi periode observasi (t) dan (t-1). Simbol variabel DEF diukur empat indikator dengan formulasi di bawah ini. (Frank and Goyal 2003) (Gracia and Mira 2008)

DEF $=\{$ (Dividend $+\Delta$ Fixed Asset $+\Delta$ Net Working Capital $)-$ Cash flow after interest $\&$ tax $\}$

Pengukuran indikator deficit financial meliputi :

- Dividend $=$ Dividend payment $(\mathrm{t})$

- $\Delta$ Fixed asset $=\{$ Fixed asset $(\mathrm{t})-$ Fixed asset $(\mathrm{t}-1)\}$ 
- $\Delta$ Net working capital $=\{$ Net working capital $(\mathrm{t})$ - Net working capital (t-1) $\}$

- Cash flow after interest \& tax = Earning after interest \& tax (t)

Keterangan:

Dividend payment $=$ Pembayaran dividen

$\Delta$ Fixed asset $=$ Perubahan aktiva tetap

$\Delta$ Net working capital $=$ Perubahan modal kerja bersih

Net working capital $=($ Aktiva lancar - Utang lancar $)$

Cash flow after interest $\&$ tax $=$ Laba bersih setelah bunga pinjaman $\&$ pajak

\section{Teknik Analisis Data}

Teknik analisis menggunakan nilai rata-rata, regresi sederhana dan ganda dengan persamaan sebagai berikut:

$\mathbf{Y}_{\Delta \text { Debt }}=\alpha+\beta$ Dividend $+\beta \Delta$ Investment $+\beta \Delta \mathrm{NWC}+\beta I C F+e$

$\mathbf{Y}_{\Delta \text { Debt }}=\alpha+\beta$ Def $+\mathbf{e}$

..... Pers. 1

..... Pers. 2

Spesifikasi pengujian Pecking Order Theory menggunakan kriteria sebagai berikut: (1) Nilai konstanta atau $\alpha$ diharapkan rendah atau mendekati nol. (2) Tanda $\beta$ diharapkan Dividend (+), Invest $(+), \Delta \mathrm{NWC}(+)$, ICF (-) di Pers. 1. (3) Tanda $\beta$ diharapkan Def (+) dengan nilai mendekati 1 di Pers. 2. Dengan mengacu Chirinko and Singha (2000), (Shyam-Sunder and Myers (1999) apabila menghasilkan nilai konstanta $(\alpha)$ mendekati 0, koefisien ( $\beta$ po) DEF positif mendekati 1 artinya: tambahan utang sebanding dengan besarnya deficit financial dengan diikuti nilai $\mathrm{R}^{2}$ relatif tinggi. Jika tidak demikian berarti pecking order tidak berlaku dalam sistem pendanaan.

\section{HASIL DAN PEMBAHASAN}

Tabel 1 menunjukan perbedaan rata-rata peningkatan utang jangka panjang suatu periode ke periode berikutnya. Dari total observasi defisit finansial tercatat Rp. 271.210.400.000,- dengan rata-rata penambahan utang jangka panjang sebesar 23.23\%, sedangkan surplus finansial tercatat Rp. 264.425.000.000,- dengan rata-rata penambahan utang jangka panjang sebesar $15.71 \%$.

Tabel 1. Perbedaan Penambahan Utang Jangka Panjang

\begin{tabular}{|c|c|c|c|}
\hline \multicolumn{2}{|c|}{ Kondisi Deficit Financial (51\%) } & \multicolumn{2}{c|}{ Kondisi Surplus Financial (49\%) } \\
\hline Rata-Rata Nilai Defisit & Rata-Rata LTD & Rata-rata Nilai Surplus & Rata-Rata LTD \\
\hline Rp. 271.210.400.000,- & $23.23 \%$ & Rp. 264.425.000.000,- & $15.71 \%$ \\
\hline
\end{tabular}

Ketika surplus berarti kondisi pendanaan memiliki cukup sumber internal sehingga lebih sedikit menggunakan sumber dana utang pada periode berikutnya. Sebaliknya, ketika defisit berarti pengeluaran kas (cash disbursement) berupa: dividen, penambahan fixed asset dan penambahan modal kerja bersih melebihi dari internal cash flow. Salah satu cara mengatasi defisit dengan menambah utang jangka pendek (nonspontanous debt) kemudian menggunakan long term debt atau emisi saham baru. Riset ini sebatas mengkaji penambahan utang jangka panjang, dengan demikian cakupan kajian tidak sampai menelaah kemungkinan saham baru. Berdasarkan 292 observasi teridentifikasi "Adanya perbedaan rata-rata utang jangka panjang antara kondisi defisit dan surplus finansial" atau disimpulkan Ha tidak ditolak.

Pengujian kedua mengindikasikan nilai $\mathrm{R} 48.50 \%$ dan $\mathrm{R}^{2} 23.50 \%$ dengan adjusted $\mathrm{R}^{2} 22.40 \%$. Artinya sebesar $22.40 \%$ perubahan total utang diprediksi oleh dividen, investasi, $\triangle \mathrm{NWC}$ dan ICF, sedangkan sisanya $77.60 \%$ diprediksi faktor lain. Mengacu dengan riset sebelumnya arah koefisien indikator DEF yaitu: Dividend (+), Invest fixed asset $(+), \triangle \mathrm{NWC}(+)$, ICF $(-)$ sesuai dengan tanda diharapkan dan signifikan terhadap perubahan total utang. Hasil persamaan regresi sebagai berikut:

$\mathrm{Y}_{\Delta \mathrm{Debt}} \quad=24911.090+0.526$ Dividend $^{*}+0.247$ Invest $^{*}+0.167 \Delta \mathrm{NWC}^{*}-0.311 \mathrm{ICF}^{*}$

Nilai uji $\mathrm{t} \quad=(1.049) \quad(3.542) \quad(7.783) \quad(4.554) \quad(-5.506)$

Sig uji $\quad=\left(\begin{array}{llll}(0.295) & (0.000) & (0.000) & (0.000)\end{array}\right.$

Sig uji $\mathrm{F} \quad=22.081 \quad(0.000)$

Keterangan: *sig $1 \%(0.000<0.001)$ 
Disimpulkan tanpa mempertimbangkan 4 indikator keputusan pendanaan cenderung menambah total utang senilai Rp. 24.911.090.000. Berdasarkan 292 observasi teridentifikasi arah koefisien masing-masing indikator sesuai kriteria pengujian parsial maupun bersama-sama signifikan 1\%. Teridentifikasi: (1) Pembayaran dividen memiliki pengaruh positif signifikan $1 \%$ terhadap perubahan total utang. Ketika dividen menurun berarti perusahaan memiliki porsi laba ditahan relatif tinggi sehingga kebutuhan dana investasi dipenuhi melalui internal financing atau menekan utang. Meskipun tidak semua observasi secara kontiyu membagi dividen, tetapi efek dividen signifikan terhadap perubahan utang. Ketika dijumpai keputusan deviden nol berarti makin menambah laba ditahan sehingga menurunkan penggunaan utang. (2) Keputusan investasi jangka panjang (penambahan aset tetap) memiliki pengaruh positif signifikan $1 \%$ terhadap perubahan total utang. Ketika investasi bertambah akan meningkatkan kebutuhan dana sehingga kebutuhan dana investasi dipenuhi melalui penambahan utang. (3) Keputusan penambahan modal kerja memiliki pengaruh positif signifikan $1 \%$ terhadap perubahan total utang. Penambahan modal kerja sebagian telah didanai utang jangka pendek sehingga cenderung meningkatkan total utang. Karena investasi dalam modal kerja bertambah, peningkatan aktiva dipenuhi melalui penambahan utang. (4) Sumber dana internal memiliki pengaruh negatif signifikan $1 \%$ terhadap perubahan total utang. Kemampuan menghasilkan laba ditahan terkait dengan keputusan dividen sehingga memberikan efek negatif terhadap utang. Jika dilihat dari arah hubungan empat variabel tersebut sesuai dengan Khan \& Adom (2015). Berdasarkan hasil di atas teridentifikasi "Indikator DEF terdiri dividen, perubahan aktiva tetap, perubahan modal kerja bersih dan arus kas internal secara parsial signifikan memprediksi pertumbuhan total utang" atau disimpulkan $\mathbf{H a}_{2}$ tidak dapat ditolak.

Pengujian ketiga mengindikasikan nilai $\mathrm{R} 46.60 \%$ dan $\mathrm{R}^{2} 21.70 \%$ dengan adjusted $\mathrm{R}^{2} 21.50 \%$. Artinya sebesar $21.50 \%$ perubahan total utang diprediksi oleh kondisi deficit financial, sedangkan sisanya $78.50 \%$ diprediksi oleh faktor lain. Jumlah observasi yang mengalami surplus finansial mencapai 143 (49\%) sedangkan sisanya sebesar 51\% mengalami deficit financial. Hasil regresi sederhana sebagai berikut:

$\mathrm{Y}_{\triangle \mathrm{Debt}} \quad=21176.323+0.214$ Def* $^{*}$

Nilai uji $\mathrm{t} \quad=(0.944) \quad(8.971)$

Sig uji $\quad=(0.346) \quad(0.000)$

Sig uji $\mathrm{F} \quad=(80.486) \quad(0.000)$

Keterangan: * signifikan $1 \%(0.000<0.001)$

Disimpulkan tanpa mempertimbangkan kondisi defisit financial, perilaku pendanaan cenderung menambah total utang senilai Rp. 21.176.323.000. Nilai koefisien $\beta$ DEF positif 0.214 signifikan $1 \%$ dengan $\mathrm{R}^{2}$ $21.70 \%$. Jika terjadi kondisi deficit financial, maka untuk memenuhi keterbatasan finansial akan digunakan sumber dana utang. Dengan demikian total utang akan meningkat sebesar Rp. 214.000.000,- Sebaliknya, ketika kondisi surplus financial, maka kelebihan kas akan digunakan untuk melunasi sebagian utang, sehingga total utang cenderung menurun. Jika dilihat dari arah positif deficit financial sesuai dengan Atiyet (2012) dan Khan \& Adom (2015). Hasil mengindikasikan bahwa "Kondisi defisit finansial secara positif signifikan mampu memprediksi pertumbuhan total utang" atau disimpulkan $\mathbf{H a}_{3}$ tidak dapat ditolak.

Persamaan diidentifikasi nilai $\alpha$ masih tinggi sebesar 21176.323 (Rp. 21.176.323.000,-) dengan koefisien $\beta$ DEF positif 0.214 (Rp. 214.000.000,-) dengan $\mathrm{R}^{2}$ sebesar 21.70\%. Artinya hasil analisis belum sepenuhnya konsisten dengan POT karena: (1) Nilai $\alpha$ masih tinggi sehingga tidak relevan dengan ShyamSunder and Myers (1999) Lemmon \& Zender (2008) yang menghasilkan nilai alpha mendekati nol. (2) Koefisien $\beta$ pada DEF positif sebesar 0.214 tidak sesuai dengan Shyam-Sunder \& Myers (1999) atau Lemmon \& Zender (2008) karena tidak sepenuhnya keputusan pendanaan menggunakan utang. (3) Nilai $\mathrm{R}^{2}$ sebesar $21.70 \%$ tidak relevan dengan Shyam-Sunder \& Myers (1999), Frank \& Goyal (2003) Lemmon \& Zender (2008) yang menghasilkan nilai $\mathrm{R}^{2}$ seharusnya tinggi. Tetapi nilai tersebut lebih sesuai dengan Khan \& Adom (2015) yang menghasilkan nilai $\mathrm{R}^{2}$ sebesar 16.79\%. Berdasarkan pertimbangan tersebut 
tersimpulkan perilaku dalam mengambil keputusan struktur modal tidak sepenuhnya mengacu dengan pecking order theory.

Kedua pengujian cenderung sesuai dengan Khan \& Adom (2015) tetapi pada penelitian tersebut membandingkan antara penambahan utang dengan penambahan ekuitas. Defisit finansial pada Khan \& Adom (2015) lebih berpengaruh kuat terhadap penambahan ekuitas dari pada utang sehingga disimpulkan hasil tidak konsisten dengan pecking order. Jika dibandingkan dengan Frank \& Goyal (2003) atau Darminto \& Manurung (2008), maka nilai koefisien defisit finansial tidak tepat memprediksi perubahan utang. Frank and Goyal (2003) mengidentifikasi nilai $\beta$ po positif signifikan 0.28 dan Darminto \& Manurung (2008) ditemukan nilai $\alpha$ sebesar 0.0371 signifikan, $\beta$ DEF positif 0.00612 tidak signifikan, $\mathrm{R}^{2}$ sebesar $25 \%$. Berdasarkan berbandingan tersebut dinyatakan pecking order tidak sepenuhnya diterapkan pada sektor manufaktur di Indonesia. Namun jika ditelaah melalui arah koefisien Dividend $(+)$, Investment $(+), \Delta \mathrm{NWC}$ $(+)$ ICF (-) maka hasil riset ini sesuai dengan pecking order theory. Dengan demikian terdapat sinergi antara pecking order theory dengan trade off model dimana keduanya saling menggantikan penggunaanya sesuai timing atau situasi. Kajian terkait situasi tersebut dikembangkan sebagai market timing seperti pada riset sebelumnya oleh Alti (2006), Baker \& Wurgler, (2002), Huang \& Ritter (2005).

\section{SIMPULAN DAN SARAN}

Disimpulkan sebagai berikut: (1) Terdapat perbedaan rata-rata kelompok defisit vs surplus finansial dalam menentukan utang jangka panjang. Bagi kelompok perusahaan mengalami defisit finansial lebih tinggi dalam menggunakan utang jangka panjang dengan rata-rata 23.23\%. Sebaliknya, perusahaan mengalami surplus menentukan utang jangka panjang sebesar 15.71\%. (2) Terdapat pengaruh signifikan 4 indikator defisit finansial dalam memprediksi pertumbuhan utang, dimana dividend, investment dan $\Delta \mathrm{NWC}$ memiliki pengaruh positif signifikan sedangkan ICF berpengaruh negatif dengan signifikan $1 \%$ terhadap peningkatan/penurunan utang. (3) Terdapat pengaruh signifikan antara defisit finansial dalam memprediksi pertumbuhan utang di tingkat $1 \%$. Ketika menghadapi kondisi deficit financial, keputusan pendanaan menggunakan utang sedangkan ketika surplus finansial digunakan melunasi utang. (4) Terkait dengan penerapan pecking order theory maka hasil kajian belum sepenuhnya selaras dengan teori tersebut. Simpulan tersebut dikarenakan tidak dapat memenuhi kriteria dari asumsi pecking order theory seperti referensi Khan \& Adom (2015), Shyam-Sunder \& Myers (1999), Frank \& Goyal (2003), Lemmon \& Zender (2008). Sebagai saran perlu mempertimbangkan variabel lain memprediksi penggunaan utang serta dikembangkan dengan model estimasi lain untuk menguji penerapan pecking order theory. Model estimasi berbasis GMM (Generalized Method Moment) mungkin dapat digunakan untuk pengujian pecking order pada penelitian selanjutnya, seperti digunakan dalam Gracia \& Mira (2008).

\section{REFERENSI}

Akhtar, S. (2005). The determinants of capital structure for australian multinational and domestic corporations. Journal of management, vol 30. No: 2. 321-341.

Alti, A. (2006). How to persistent is the impact of market timing on capital structure? The Journal of Finance, vol LXI, No. 4 August, 1681-1709.

Atiyet, B.A. (2012). The pecking order theory and the static trade off theory: Comparison of the alternative explanatory power in French Firms, Journal of Business Studies Quartery., 1-14.

Baker, M. \& Wurgler, J. (2002). Market timing and capital structure., The Journal of finance, vol LVII, 132.

Chen, J. and Strange, R. (2006). The determinants of capital structure: Evidence from Chinese listed companies, economic change and restructuring, 38, 11-35.

Chirinko. R. S. And Singha, A. (2000). Testing static trade off againt pecking order models of capital structure: a critical comment, Journal of Financial Economic 58, 417-425.

Cotei, C. and Farhat, J. (2009). The trade-off theory and the pecking order theory: are they mutually exclusive? North American Journal of Banking Research, vol 3, 1-16.

Darminto \& Manurung A. (2008). Pengujian teori trade off dan teori pecking order dengan satu model dinamis pada perusahaan public di Indonesia, Jurnal Manajemen Bisnis, vol 1. No: 1, 35-52. 
Fama, E. F. and Frenc, K. (2002). Testing trade-off and pecking order prediction about dividend and debt, Review of Financial Studies, 15, 1-33.

Fosberg, R. H. (2008). Debt capacity and debt financing, Journal of Business \& Economic Research, vol. 6, no: 8, 21-26.

Frank, M.Z. and Goyal, V. K. (2003). Testing the pecking order theory of capital structure, Journal of Financial Economics, 67, 217-248.

Gracia, J. L. and Mira, F. S. (2008). Testing trade-off and pecking order theories financing SMEs, Small Business Economic, 31, 117-136.

Huang. R and Ritter. J.R. (2005). Testing the Market Timing Theory of Capital Structure, Working paper from University of Florida, 1-44.

Khan. A.S. and Adom, A.Y. (2015). A test of the pecking order theory of capital structure in corporate finance. Accounting \& Taxation. Vol 7 N0. 2, 43-49.

Mihov, V. (2005). The effect of financial deficit and target leverage on capital structure and debt characteristics: Evidence from first-time debt issuers, Research paper series,1-47.

Sekaran, U. (2003). Research Methods For Business: A Skill Building Approach, International Edition, John Willey \& Sons, USA.

Sen, M. and Oruc. E. (2008). Testing of pecking order theory in Istanbul stock exchange market, International Research Journal of Finance and Economic, 21,1-26.

Shyam-Sunder, L. and Myers. S.C. (1999). Testing static trade off againt pecking order model of capital structure, Journal of Financial Economic 51, 219-244.

Vidal, J. S. and Ugedo. J. F. (2005). Financing preference of Spanish firms: evidence on the pecking order theory, Review of Quantitative Finance and accounting, 25, 341-355.

Viviani, J. L. (2008). Capital structure determinants: an empirical study of French companies in the wine industry, International of Wine Business Research, vol. 2, No: 2, 121-194. 